\title{
ANALYSIS OF LANDSLIDE REACTIVATION USING SATELLITE DATA: A CASE STUDY OF KOTRUPI LANDSLIDE, MANDI, HIMACHAL PRADESH, INDIA
}

\author{
N. Singh ${ }^{1}$, S. K. Gupta ${ }^{1, *}$, D. P. Shukla ${ }^{1}$ \\ ${ }^{1}$ School of Engineering, Indian Institute of Technology Mandi, India (*sharadgupta27@gmail.com)
}

KEY WORDS: Temporal Change detection, Reactivated Landslide, Kotrupi (HP), Google Earth, Geomorphological Analysis, Remote Sensing

\begin{abstract}
:
Landslide is a global natural hazard that occurs frequently in the areas of incompetent weak rocks, undulating topography, steep slopes and incessant rainfall. In the night of 12 August 2017, a massive landslide took place at Kotrupi, Mandi district, Himachal Pradesh, India. The slide was so huge that it eroded more than 300-meter stretch of NH-154 killing over 50 people with more than 40 missing. Local residents report that this area has always been unstable where small landslides had occurred in the past. The landslide scar could be seen on the past satellite images from December 2001 to March 2017 on Google Earth. A huge landslide occurred at this location on 13 August 1977. After two decades on 13 August 1997, the landslide reactivated and some part of the slope failed, which can be seen on satellite images of the year 2001. The landslide reactivated again on 13 August 2007, but not much attention was given to it, as it was a small event and did not affect much. Again, after a decade, in the night of 12 August 2017 this landslide was reactivated. There is the possibility of reoccurrence of slope instability from upper reaches of the crown area of the main slide complex as well as the debris, which have been already accumulated on hill and valley side. Based on the geological, geotechnical and geophysical investigations the site stability can be done but its monitoring from satellite provides the information for its future preventive measures.
\end{abstract}

\section{INTRODUCTION}

The Himalayan mountain range runs from West-Northwest to East-Southeast in an arc of $2400 \mathrm{~km}$ length having rich geo-diversity. The increasing population along the range and at the foothills have increased anthropogenic activities (Pande, Uniyal, 2007, Ray et al., 2007). Increased human activities are the main drivers for changing climate, extreme events and geomorphological changes in the Himalayan region (Petley et al., 2007, Bennett et al., 2016, Froude, Petley, 2018). Climate change can affect t he t iming, s ize, a nd f requency o f natural hazards in the Himalaya in an uncontrolled manner with changing topography (Haritashya et al., 2006). The steep slopes with thin soil cover without any vegetation, over impervious bedrock and high orographic precipitation are the favorable conditions for landslides and floods in the Himalayan region (Haritashya et al., 2006). Being the youngest mountain range in the world and structurally unstable, Himalayan region is highly prone to topographically controlled natural hazards.

Globally, many lives are lost, huge amount of properties and revenue is lost each year due to landslide (Lee, Pradhan, 2007, Tiwari, Ajmera, 2017). Global landslide database shows that distribution of landslide is heterogeneous, have caused largest causalities in Asia especially in the Himalayan region (Froude, Petley, 2018). Landslides are more prevalent in the Himalayan region mainly due to varying lithology, changing weather, extreme precipitation, density of drainage, tectonic activities, orography, topography, and ongoing seismicity (Ray et al., 2007, Pareek et al., 2010, Tiwari, Ajmera, 2017). Precipitation coupled with weak lithology and unattended slope mitigation leads to pervasive landslides along road corridors, which impose high risk on urban settlements (Lee, Pradhan, 2007, Kundu et al., 2013, Sarkar et al., 2015, Bennett et al., 2016, Froude, Petley, 2018).

The present landslide was caused due to reactivation of already three times failed slope, which have occurred at about 20-year regular interval since 1977. Locals recall that scarp had already started developing due to slope failure on 13 August 1977 (GSI 2017). After two decades,

${ }^{*}$ Corresponding author on 13 August 1997, the landslide reactivated, and scarp widened in dimensions. Again, on 13 August 2007, slide reactivated, but the slope failure was not large and did not affect $\mathrm{p}$ eople, $\mathrm{h}$ ence $\mathrm{n}$ ot $\mathrm{m}$ uch a ttention $\mathrm{w}$ as given. In 2018 as well, the slide reactivated but since the slope failure was not that prominent, again not much attention was given. However, the landslide event in August 2017 was most devastating. The people residing in the area of landslide zone (near toe and run off zone) were concerned about the reactivation of the landslide in future as it had happened in past. If that happens then their livelihood will be at stake.

The repetitive nature of the landslide is the major concern in the study area. Here, we have carried out detailed analysis of geological, seismicity, climatic and soil moisture data to understand the probable cause of this deadly landslide. We visited the landslide site many times i.e. November 2017, August 2018, February 2019, April 2019. We carried out detailed geological field investigations. Further, we analyzed meteorological and seismic data to understand the possible triggering and reactivation of the landslide. We have used past satellite images for analysis of landslide reactivation.

\section{STUDY AREA}

The Kotrupi landslide is located on Mandi - Joginder Nagar - Pathankot National Highway (NH)-154 with center coordinates of $31^{\circ} 54^{\prime} 46.29$ ' $\mathrm{N}$ and $76^{\circ} 53$ '31.90" $\mathrm{E}$ (as shown in Figure. 1). The landslide falls in seismic zone $\mathrm{V}$, which represents highly vulnerable seismic area. The landslide lies in the Mandi district which is geographically located within $31^{\circ} 13^{\prime}-32^{\circ} 05^{\prime} \mathrm{N}$ latitudes and $76^{\circ} 37^{\prime}-$ $77^{\circ} 25^{\prime} \mathrm{E}$ longitudes. The area of the slide is measured to be around $133,674 \mathrm{~m} 2$ and width is $190 \mathrm{~m}$, while the runout length is $1155 \mathrm{~m}$ as seen on high-resolution satellite image. The elevation of the district varies between $550 \mathrm{~m}$ to $3960 \mathrm{~m}$ a.m.s.l. Mandi district has varying climate from sub-tropical climate in the valley area to temperate at hilltops. In high altitude regions, the weather remains colder throughout the year with snowfall above $2000 \mathrm{~m}$ a.m.s.l in winter season. The temperature varies between $30^{\circ}-40^{\circ} \mathrm{C}$ in summers in low-lying areas. The district receives good amount of rainfall in the monsoon season from July to 
September along with sporadic rainfall in post winters season i.e. February to March due to western disturbances. The annual average rainfall of Mandi district is 1331.50 $\mathrm{mm}$, which varies in between $700-2000 \mathrm{~mm}$ from place to place (CGWB report 2013).

\subsection{Landslide Event on 13 August 2017}

A massive landslide occurred near Kotrupi village in Mandi district during early hours of 13 August 2017 (01:00-02:00 AM local time). The debris from landslide killed more than 50 people when two HRTC (Himachal Road Transport Corporation) buses (i.e. Manali-Katra and Chamba-Manali) along with other private vehicles were swept away and buried under the debris (Roy et al., 2018, Sharma et al., 2018, Pradhan et al., 2019) (GSI 2017). As per the reports, approximately six bodies were recovered from first $\mathrm{b}$ us, w hereas $\mathrm{n}$ othing $\mathrm{c}$ ould $\mathrm{b}$ e recovered from second bus (Pradhan et al., 2019). News reports suggests that approximately $300 \mathrm{~m}$ of road stretch of national highway (NH-154) has been completely buried under debris, thus disrupting communication on an important route. Immense quantity of debris released from the landslide blocked the drainage up to $1 \mathrm{~km}$ in the downstream. The area was subsiding due to presence of nallas, which made the region swampier. Due to this catastrophe, the new alignment of the NH was carried out by Public works department (PWD). As the Kotrupi landslide witnessed minor scarp failure in July 2018, the road was washed off and the authorities changed the road alignment again. The present stretch of NH-154 follows the same alignment, which existed before the incident of 13th August 2017. The Kotrupi landslide and the road alignments are shown in Figure-1.

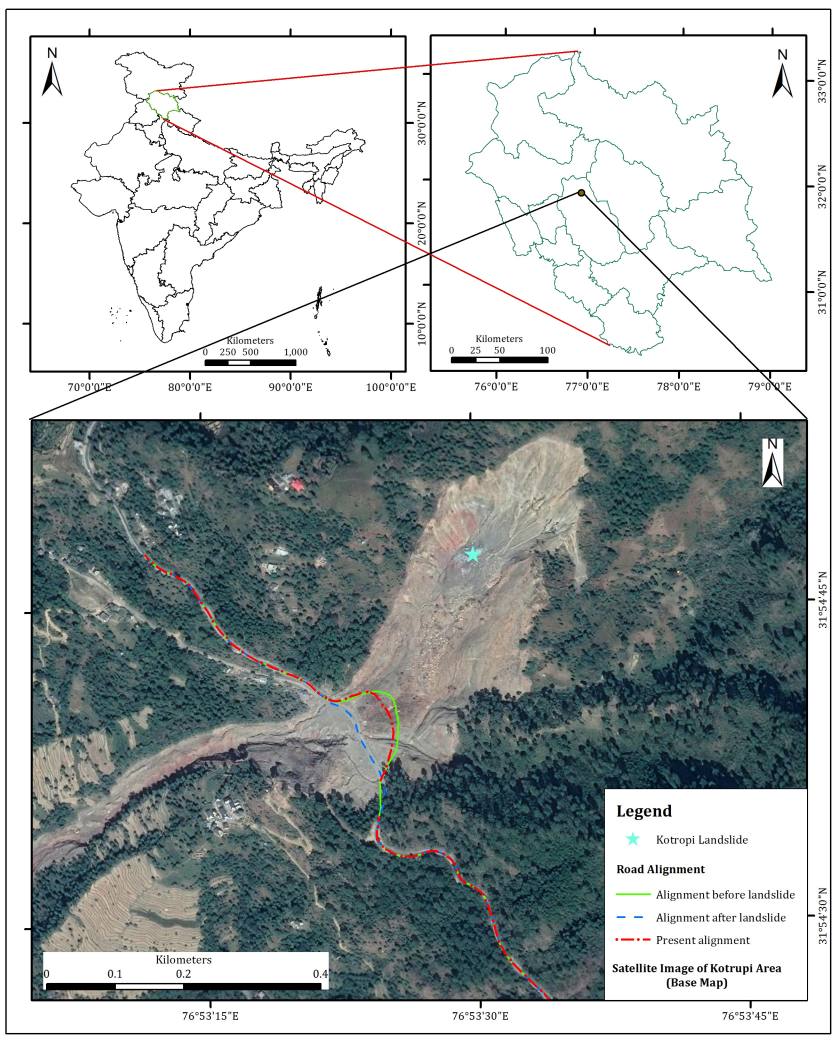

Figure 1. Kotrupi landslide location as seen on satellite images. The present road alignment, before landslide and change in alignment soon after the landslide are shown with red, green and blue lines

\subsection{Geology of the Landslide Site}

The primary rock types found in and around the Kotrupi landslide are red shale, dolomite of Shali formation and sandstone, shale of Siwalik group (Roy et al., 2018, Sharma et al., 2018). The red shale rock present in the outcrop is loose, highly crushed and almost weathered into the soil. The shale beds are present with interspaces, which are filled with loose soil and crushed rock material. Highly crushed and thinly bedded weathered sandstone intercalated with shale beds is present at few places.

The study area (Kotrupi landslide) is sandwiched between Siwaliks and Shali formation along the thrusted contact of MBT. In the west of MBT, local faults like Drang, Jwala Mukhi and Ropar Manali faults (Thakur et al., 2019) passes as shown in Figure-2. These structural settings in the vicinity of the landslide area create favorable conditions for high vulnerability of the slope failures. Due to its weak and fragile topography and lithology, the area in between Ghatasani and Padhar region encounters many landslides. However, the Kotrupi landslide is one of its kind due to its large size and losses occurred.

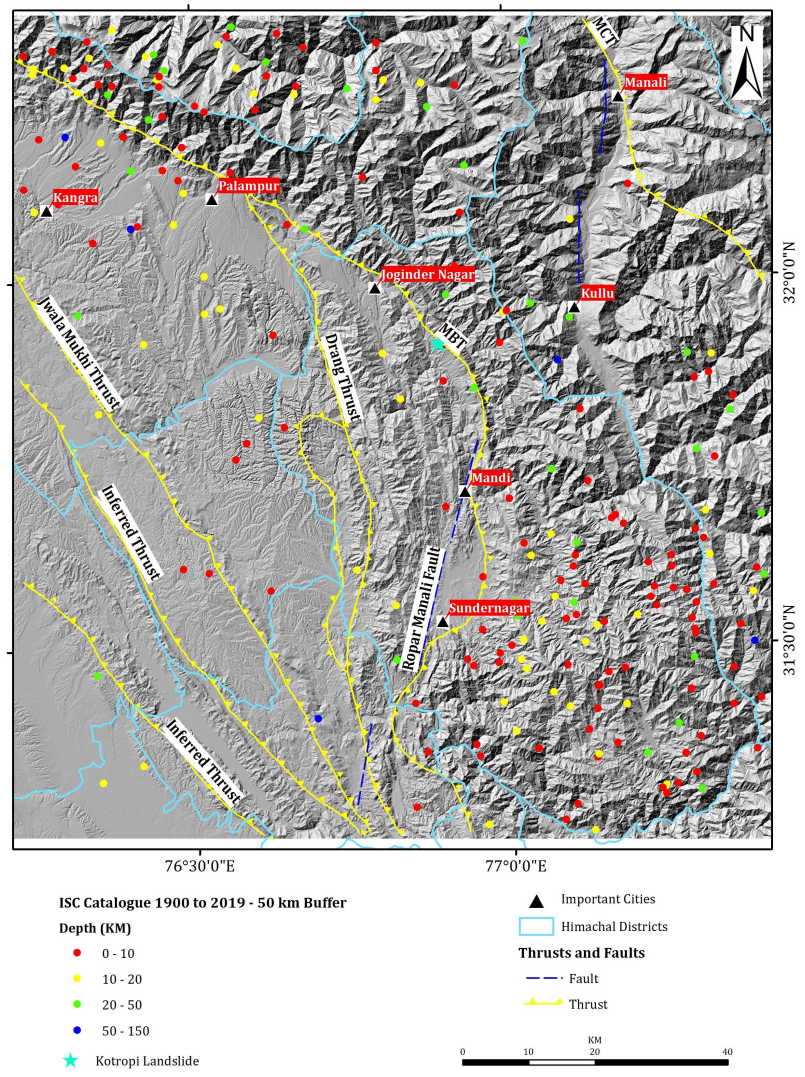

Figure 2. Ropar-Manali fault that passes through the Kotrupi landslide location. The earthquake epicenters within $50 \mathrm{~km}$ buffer zone of study a rea has been marked.

The main boundary thrust (MBT) and Main central

Thrust (MCT) is marked in the map (Modified after (Thakur et al., 2019))

\section{DATA AND METHODOLOGY}

To understand the landslide reactivation, it is important to evaluate both internal and external factors that may have caused the slope failure. We have studied the probable cause of the Kotrupi landslide using geological data, past earthquakes, precipitation and soil moisture data. The historic records of past earthquake events can unfold the future aspects of seismic activities in the Himalayan 
region (Bilham, 2019). Hence, we have analyzed the frequency and magnitude of the earthquakes within $50 \mathrm{~km}$ radius around the Kotrupi landslide that have occurred during 1970-2018. In addition, landslide inventory was also prepared to understand the past activities and relate it to mass movements in the region. Earthquake data for the study area was collected from International Seismic Centre (ISC) for the period 1970-2016. While for the years 2017 and 2018, United States Geological Survey (USGS) earthquake data inventory was utilized.

The daily rainfall data with the spatial resolution of $0.25^{\circ} \mathrm{X} 0.25^{\circ}$, was collected from TRMM (Tropical Rainfall Measuring Mission) satellite for the months of July and August 2010 - 2018. The daily data was used for studying the effect of unprecedented rainfall prior to the failure of the slope. The 3-hourly data of soil moisture with the spatial resolution of $0.25^{\circ} \mathrm{X} 0.25^{\circ}$ at depth levels $1-10,10-40,40-100$ and $100-200 \mathrm{~cm}$, was collected from GLDAS (Global Land Data Assimilation System). The 3 hourly data were converted into daily data for correlating with the daily rainfall data. However, we have found that the microwave satellite data is not sensitive to soil moisture at higher depth more than $20 \mathrm{~cm}$ in Himalaya terrain due to presence of thin soil cover and dense vegetation.

\section{RESULTS AND DISCUSSIONS}

The Kotrupi landslide is one of the biggest of its type that took place in Himachal Pradesh. The initial report suggested that it occurred due to excessive rainfall. However, landslide scar can be seen on the previous year's satellite images from December 2001 to March 2017 on Google Earth. From the satellite images, it can be inferred that this catastrophe is not a mere one-day event rather decades-long process. Cracks were developed well before the occurrence of the event; however, rainfall might have triggered the slide. Local residents report that this area has always been unstable where small landslides had occurred in the past. A huge landslide occurred at this location on 13 August 1977. After two decades on 3 August 1997, the landslide reactivated and some part of the slope failed, which can be seen on satellite images of the year 2001 (Figure3). The landslide reactivated again on 13 August 2007, but not much attention was given to it, as it was a small event and did not affect much. Again, after a decade, in the early hours of 13 August 2017 this landslide was reactivated. The Figure 3 shows various images of Kotrupi area prior to landslide and after landslide. The scar can be seen expanding from surficial c rack t o $\mathrm{m}$ assive 1 andside f rom 2001 t o 2018 in Figure-3(a)-3(h).

We have considered both external and internal factors such as rainfall, slope, soil moisture, lineament density, faults (local and regional), earthquakes and lithology, to understand the reactivation of Kotrupi landslide.

\subsection{Magnitude and Frequency of Earthquakes}

To understand the impacts of external factors such as earthquakes on the landslide and surrounding region, the earthquake event data was analyzed. The magnitude and frequency of earthquakes are shown in Figure-4(a) and 4(b). During 1970-1997, total 97 earthquakes (mostly shallow, depth $10-20 \mathrm{~km}$ \& magnitude 4-5) were recorded, whereas 272 earthquakes (magnitude $>5.0$ ) were recorded during 1997 to 2018, which indicate an increase in the frequency of the earthquakes in recent years. The depth of an earthquake plays an important role in controlling the topography of any region. Shallow earthquakes with high magnitude in weak and fragile topography damage more as compared to a deep-seated earthquake. Some of the great examples of earthquake-induced landslides in the past are Kangra earthquake of 1905 in

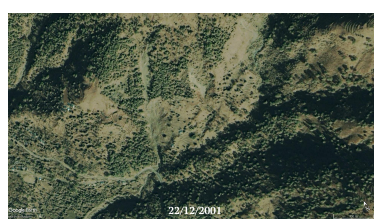

(a) 2001

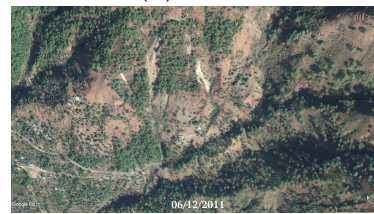

(c) 2011

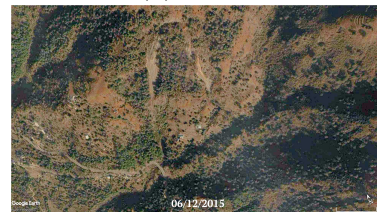

(e) 2015

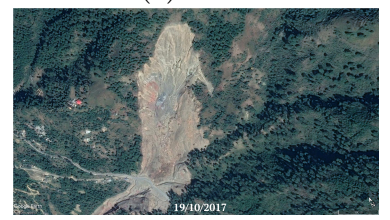

(g) 2017 - Post Landslide

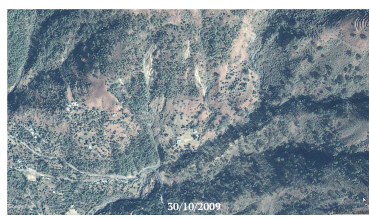

(b) 2009

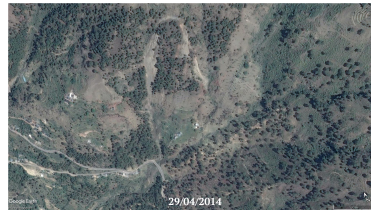

(d) 2014

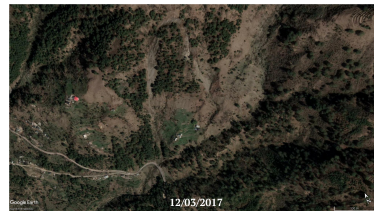

(f) 2017 - Pre Landslide

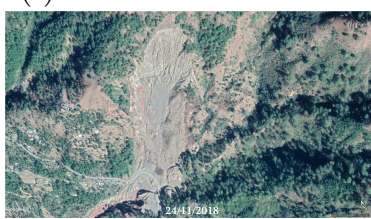

(h) 2018
Figure 3. Landslide Reactivation - The existence of crack (Year 2001) can be clearly seen in (a). The development and enlargement of crack can be seen in subsequent images (b)-(f). Landslide occurrence can be seen in (g) and (h). Change in Road alignment is also visible

the Himachal Pradesh, Uttarkashi earthquake 1991 of Uttarakhand and Gorkha earthquake in Nepal of 2015 (Pradhan et al., 2006).

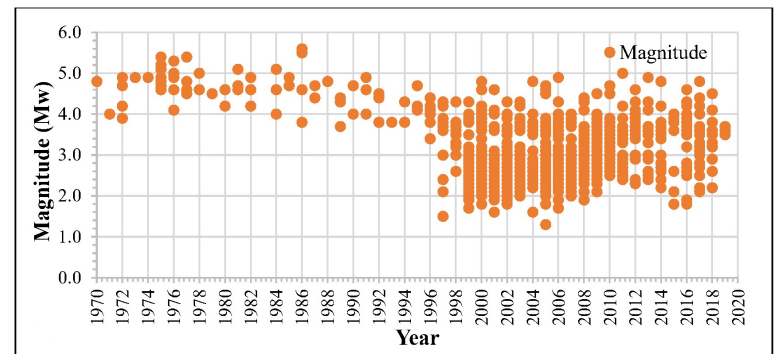

(a)

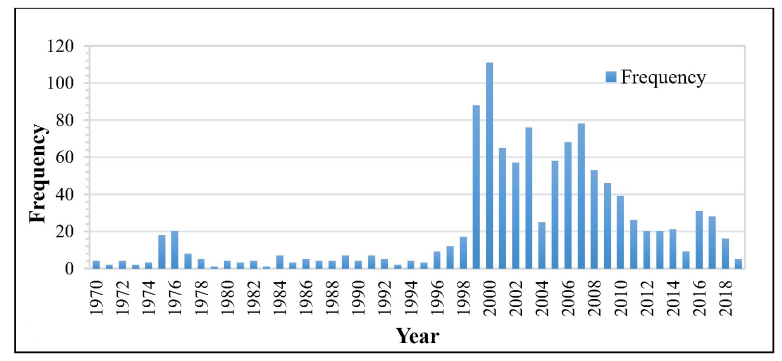

(b)

Figure 4. (a) Magnitude and (b) Frequency distribution of earthquakes for the periods 1970-2018 occurred within $50 \mathrm{~km}$ radius of the Kotrupi landslide

Nearly $55 \%$ of the earthquakes which have occurred within $50 \mathrm{~km}$ radius of study area, are shallow earthquake with focal depth of 10-20 km as given in Table-1. Shallow earth- 
quakes of 4-5 Mw magnitude tends to be very violent especially if the geology of the area is weak and fragile. Earthquakes have triggered landslides in and around epicenter of earthquakes specially if the earthquake is of shallow type (Pradhan et al., 2006). The depth of MBT is observed to be about $10 \mathrm{~km}$ while the depth of MCT is around 10$20 \mathrm{~km}$ near Kotrupi landslide (Thakur et al., 2019). From the earthquake events occurred in the vicinity of Kotrupi it can be established that MCT is still active around Kotrupi landslide site.

Table 1. Number of earthquake events occurred within the radius of $50 \mathrm{~km}$ of the landslide location at different depths.

\begin{tabular}{|c|r|r|}
\hline S. No. & $\begin{array}{r}\text { Depth of occurrence } \\
\text { of the earthquake }(\mathrm{km})\end{array}$ & $\begin{array}{c}\text { No of events } \\
\text { of earthquakes }\end{array}$ \\
\hline 1 & $<10$ & 371 \\
2 & $10-20$ & 252 \\
3 & $20-35$ & 237 \\
4 & $35-50$ & 180 \\
5 & $>50$ & 106 \\
\hline
\end{tabular}

\subsection{Rainfall as Triggering Factor for Landslide}

The hydrologic characteristics of the slope, shear stress acting on the slope and the mechanical resistance along potential slip surface plays a prominent role in affecting the failure mechanism of the slope (Berti et al., 2012). Although the correlation between precipitation and landslides is well known, it's invariably a vital question to ask what affects the occurrence of landslides more, antecedent rainfall (i.e. rainfall in the days immediately preceding a landslide event) or triggering rainfall (i.e. rainfalls at the time that the landslide occurs) (Rahardjo et al., 2001). We have tried to understand the variation in soil moisture with rainfall for the months of July and August from 20102018. During August 2017, total $293.88 \mathrm{~mm}$ rainfall was recorded, however, $194.81 \mathrm{~mm}$ rainfall occurred between 05-13 August and only $99.07 \mathrm{~mm}$ rainfall was recorded on other days which can be seen in Figure- 5 .

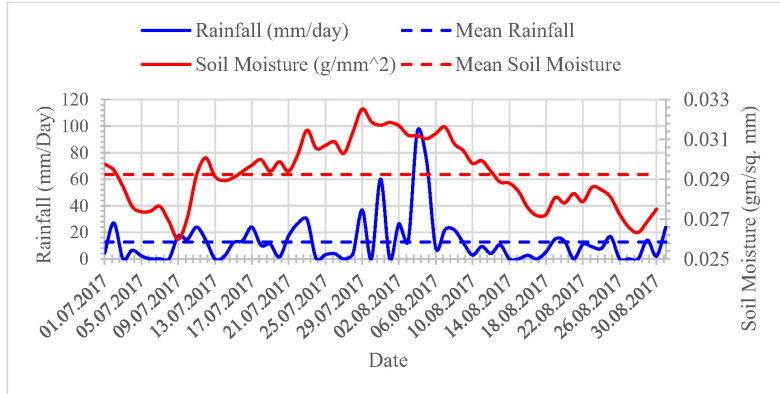

Figure 5. Variations of rainfall with soil moisture for the months of July-August 2017

This seven-day antecedent rainfall intensity prior to landslide was $1.19 \mathrm{~mm} / \mathrm{hr}$. As already discussed, the rocks present within the vicinity of the sliding area are highly crushed and weathered. The low rainfall intensity with continuous downpour may have allowed water to percolate within the rock formation/slope. The percolated water may have increased pore water pressure which further reduced the strength of the rock/soil lying between MBT and MCT thrusts. It is evident from Figure 5 that the failure of slope on 13 August 2017 could be a consequence of unprecedented rainfall occurred 5-7 days prior to landslide.

\subsection{Effect of Rainfall on Soil Moisture}

The study of antecedent soil moisture content is necessary to understand the hydrologic response of a hilly slope in controlling the landslide incidence (Tohari, 2018). Excessive precipitation can trigger landslide in two ways i.e. either by saturating the pore water pressure or by flooding the area which further leads to surface erosion and expose the slope profile p resent b eneath (Dortch e t al., 2009). In the Figure-6, we have shown the soil moisture $(\mathrm{gm} / \mathrm{mm} 2)$ variations at depth of $0-10 \mathrm{~cm}$ and rainfall (mm/day) within the landslide location for the month of July and August from 2010 to 2018. The rainfall and soil moisture vary from $30 \mathrm{~mm} /$ day and $0.031 \mathrm{~g} / \mathrm{mm} 2$ on 25 July 2017 to $96 \mathrm{~mm} /$ day and $0.032 \mathrm{~g} / \mathrm{mm} 2$ on 06 August 2017 respectively. Although the soil moisture and rainfall follow the same trend, there is a time lag of 2-3 days. Similarly, graphs plotted for 2010 to 2018 for rainfall and soil moisture content shows that both parameters follow the same trend for previous years as well (Figure6). It is evident that, the rainfall intensity and hence soil moisture starts rising by the end July month (between 25-28) which was observed during the Kotrupi landslide as well.

The landslide might have happened due to a combination of following geo-scientific c auses: $d$ evelopment of tension cracks, sheared/thrusted rock mass having poorly drained slope, antecedent rainfall, rise in soil moisture content as well as increased seismic activities, however the single cause of failure cannot be reached. There is the possibility of re-occurrence of slope instability from upper reaches of the crown area of the main slide complex as well as the debris, which have been already accumulated on hill and valley side.

\section{CONCLUSIONS}

In this study, we have analyzed various parameters such as seismic, hydro-meteorological, soil moisture, geology and lineaments which are likely responsible for triggering the Kotrupi landslide on National Highway (NH-154) on the night of 13 August 2017. This landslide is the biggest of its type that took place in Himachal Pradesh. The recurrent behavior of Kotrupi landslide has put a lot of pressure on not only the government but also the people living near that landslide. The preliminary reports prepared by various agencies suggested that it occurred due to excessive rainfall, however the effect of antecedent rainfall was not considered.

Moreover, the landslide scar could be seen on the satellite images from December 2001 to March 2017 on Google Earth. The earlier occurrences of small landslides already carved the way for bigger landslides which was waiting to happen. This was also confirmed b y local residents who have witnessed all the small incidents happening in the landslide regime. The freely available multi-temporal satellite images from Google Earth provides a good platform for comparative study and analyzing the continuous behavior of recurrent slides.

About $55 \%$ of the earthquakes occurred at shallow depth during 1970-2019. The frequency of earthquakes within $50 \mathrm{~km}$ radius of the landslide has increased from 1997. However, the magnitude varies in between 4-5. The area as mentioned above lies in between MCT and MBT and is crossed by several local and regional faults that makes the area highly prone to seismic activity. The highly crushed and weathered rock in the vicinity is the proof of stress accumulation within the region, which has repeatedly vented out in form of slope failure.

Daily soil moisture and rainfall data for the months of July and August was utilized for a duration of 2010 to 2018 to understand the impact of rainfall and soil moisture on the observed landslide in August 2017. The rainfall 15 days prior to the landslides may have allowed 


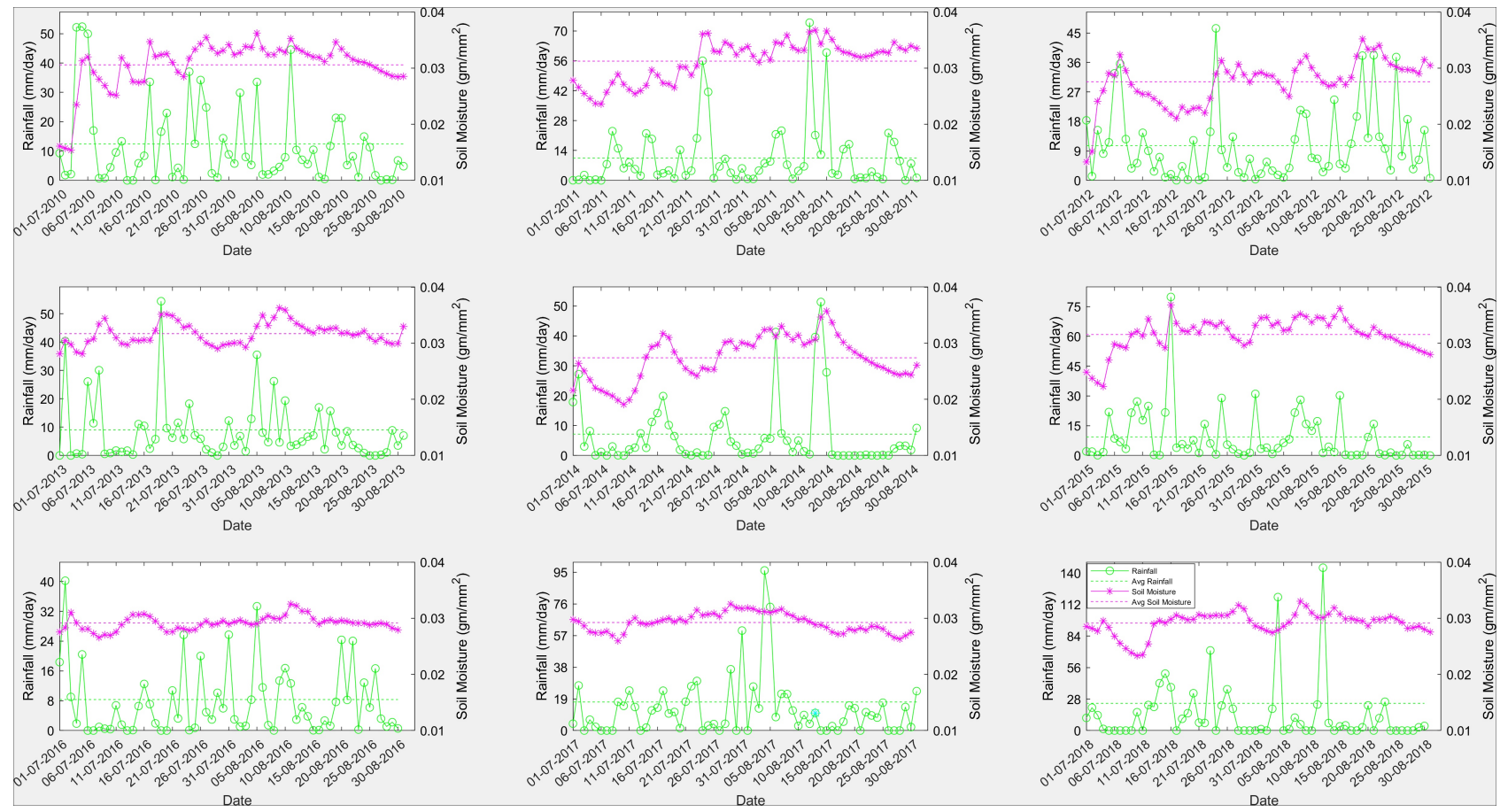

Figure 6. Soil moisture (cm) profile for July- August Months at depth of 0-10 cm with rainfall intensity for 2010, 2011, 2012, 2013, 2014, 2015, 2016, 2017, 2018 and 2019

slow infiltration/percolation of w ater i nto t he soil/rock through cracks and may have likely to increase pore water pressure leading to decrease in strength of the slope. As predicted through various models, the rainfall shows increasing trend in the future, hence the increasing rainfall could be an alarming scenario as it can directly lead to slope instability and landslide activation.

Based on the analysis carried out in the present study, it can be concluded that the reactivation of Kotrupi landslide is a combination of various causes such as development of tension cracks, sheared/thrusted rock mass having poorly drained slope, antecedent rainfall, rise in soil moisture content as well as increased seismic activities, hence the single cause of failure cannot be reached. The possibility of re-occurrence of Kotrupi landslide cannot be ignored as the debris and loose material is accumulated on hill and valley side. The slope instability from the crown area of the main slide complex is also possible as the current slide has exposed the mountain surface to open environment.

\section{ACKNOWLEDGEMENTS}

The authors would like to thank Prof. Ramesh P. Singh for sparing his valuable time and visit the landslide site. We are grateful to NASA Giovanni team for making satellite data available for the present study. We would also like to thank Google Inc. for providing Google Earth Pro. We would also like to thank USGS for providing Landat 8 images free of cost.

\section{REFERENCES}

Bennett, G. L., Roering, J. J., Mackey, B. H., Handwerger, A. L., Schmidt, D. A., Guillod, B. P., 2016. Historic drought puts the brakes on earthflows in N orthern California. Geophysical Research Letters, 43(11), 5725-5731.

Berti, M., Martina, M. L., Franceschini, S., Pignone, S., Simoni, A., Pizziolo, M., 2012. Probabilistic rainfall thresholds for landslide occurrence using a Bayesian approach. Journal of Geophysical Research: Earth Surface, 117(4), 1-20.

Bilham, R., 2019. Himalayan earthquakes: a review of historical seismicity and early 21 st century slip potential. Geological Society, London, Special Publications, SP483.16.

Dortch, J. M., Owen, L. A., Haneberg, W. C., Caffee, M. W., Dietsch, C., Kamp, U., 2009. Nature and timing of large landslides in the Himalaya and Transhimalaya of northern India. Quaternary Science Reviews, 28(11-12), $1037-1054$

Froude, M. J., Petley, D., 2018. Global fatal landslide occurrence from 2004 to 2016. Natural Hazards and Earth System Sciences, 18, 2161-2181.

Haritashya, U. K., Singh, P., Kumar, N., Singh, Y., 2006. Hydrological importance of an unusual hazard in a mountainous basin: flood and landslide. Hydrological Processes: An International Journal, 20(14), 3147-3154.

Kundu, S., Saha, A., Sharma, D., Pant, C., 2013. Remote sensing and GIS based landslide susceptibility assessment using binary logistic regression model: a case study in the Ganeshganga Watershed, Himalayas. Journal of the Indian Society of Remote Sensing, 41(3), 697-709.

Lee, S., Pradhan, B., 2007. Landslide hazard mapping at Selangor, Malaysia using frequency ratio and logistic regression models. Landslides, 4(1), 33-41.

Pande, R. K., Uniyal, A., 2007. The fury of nature in Uttaranchal: Uttarkashi landslide of the year 2003. Disaster Prevention and Management: An International Journal, 16(4), 562-575. 
Pareek, N., Sharma, M. L., Arora, M. K., 2010. Impact of seismic factors on landslide susceptibility zonation: a case study in part of Indian Himalayas. Landslides, 7(2), 191-201.

Petley, D. N., Hearn, G. J., Hart, A., Rosser, N. J., Dunning, S. A., Oven, K., Mitchell, W. A., 2007. Trends in landslide occurrence in Nepal. Natural hazards, 43(1), 2344 .

Pradhan, B., Singh, R., Buchroithner, M., 2006. Estimation of stress and its use in evaluation of landslide prone regions using remote sensing data. Advances in Space Research, 37(4), 698-709.

Pradhan, S., Panda, S., Roul, A., Thakur, M., 2019. Insights into the recent Kotropi landslide of August 2017, India: a geological investigation and slope stability analysis. Landslides, 16(8), 1529-1537.

Rahardjo, H., Li, X. W., Toll, D. G., Leong, E. C., 2001. The effect of antecedent rainfall on slope stability. Geotechnical and Geological Engineering, 19(3-4), 371-399.

Ray, P. K., Dimri, S., Lakhera, R. C., Sati, S., 2007. Fuzzybased method for landslide hazard assessment in active seismic zone of Himalaya. Landslides, 4(2), 101-111.

Roy, P., Martha, T. R., Jain, N., Kumar, V. K., 2018. Reactivation of minor scars to major landslides - a satellitebased analysis of Kotropi landslide (13 August 2017) in Himachal Pradesh, India. Current science, 115(3).

Sarkar, S., Kanungo, D. P., Sharma, S., 2015. Landslide hazard assessment in the upper Alaknanda valley of Indian Himalayas. Geomatics, Natural Hazards and Risk, 6(4), 308-325. http://dx.doi.org/10.1080/19475705.2013.847501.

Sharma, P., Rawat, S., Gupta, A. K., 2018. Study and Remedy of Kotropi Landslide in Himachal Pradesh, India. Indian Geotechnical Journal, 1-17. https://doi.org/10.1007/s40098-018-0343-1.

Thakur, V., Jayangondaperumal, R., Joevivek, V., 2019. Seismotectonics of central and NW Himalaya: plate boundary-wedge thrust earthquakes in thin-and thickskinned tectonic framework. Geological Society, London, Special Publications, 481(1), 41-63.

Tiwari, B., Ajmera, B., 2017. Landslides triggered by earthquakes from 1920 to 2015. Workshop on World Landslide Forum, Springer, 5-15.

Tohari, A., 2018. Study of rainfall-induced landslide: a review. IOP Conference Series: Earth and Environmental Science, 118, IOP Publishing. 